\title{
A simple procedure to evaluate the performance of fats and oils at frying temperatures
}

\author{
By D. Barrera-Arellano', G. Márquez-Ruiz² and M. C. Dobarganes²* \\ 1Laboratorio de Óleos e Gorduras, Facultade de Engenharia de Alimentos, Universidade Estadual de \\ Campinas. -UNICAMP- CEP 13081-97. Campinas, S.P., BRAZIL. \\ 2Instituto de la Grasa (CSIC). Avda. Padre García Tejero, 4. 41012-Sevilla, SPAIN.
}

RESUMEN

Un procedimiento simple para evaluar el comportamiento de aceites y grasas a temperaturas de fritura.

Se propone un procedimiento estándar para evaluar el comportamiento de aceites y grasas a temperaturas de fritura. En este procedimiento se utilizan las ventajas del aparato Rancimat, que permite el uso de tubos estándar, la corrección de la temperatura, en su caso, y la igualdad de temperatura en todos los tubos dadas las características del bloque de calentamiento. De los resultados obtenidos en muestras de $8 \mathrm{~g}$ de aceite calentadas a $180^{\circ} \mathrm{C}$ durante $10 \mathrm{~h}$, analizadas por triplicado, se obtuvieron coeficientes de variación inferiores al $6 \%$ para la determinación de compuestos polares y polímeros. En caso de limitación en la cantidad de aceite, se propone utilizar $2 \mathrm{~g}$ de muestra, manteniendo similares valores para la relación superficie a volumen de aceite, lo que permite obtener valores de alteración y coeficientes de variación del mismo orden. Se analizan finalmente las ventajas globales del procedimiento y sus distintas posibilidades en la evaluación de grasas de fritura. Como ejemplo, se aplica el procedimiento a la evaluación del efecto de los antioxidantes naturales de los aceites de girasol.

PALABRAS-CLAVE: Aceite de girasol -Compuestos polares - Dímeros de triglicéridos - Fritura - Método Rancimat Polímeros de triglicéridos.

\section{SUMMARY}

A simple procedure to evaluate the performance of fats and oils at frying temperatures.

A standard procedure is proposed to evaluate the performance of fats and oils at frying temperatures, taking the advantages provided by the Rancimat apparatus, i. e., standard vessels, temperature correction and temperature homogenity in all vessels resulting from the particular characteristics of the heating block. The results obtained in oil samples of $8 \mathrm{~g}$ heated at $180^{\circ} \mathrm{C}$ for $10 \mathrm{~h}$ in triplicate gave coefficients of variation lower than $6 \%$ for total polar compounds and polymers. In case of limited amount of oil, it is additionally proposed to use only $2 \mathrm{~g}$ of sample provided that a similar surface-to-oil volume ratio is maintained, and coefficients of variation of the same order than those for $8 \mathrm{~g}$ samples were thus obtained.

Advantages of the procedure as well as potential applications for evaluation of frying fats and oils are included. As an example, the effect of $a$-tocopherol on performance of sunflower oils was analyzed.
KEY-WORDS: Frying - Polar compounds - Rancimat method - Sunflower oil - Triglyceride dimers - Triglyceride polymers.

\section{INTRODUCTION}

The frying process is influenced by a number of variables among which the type of process, i.e., continuous or discontinuous, surface-to-oil volume ratio, temperature, oil unsaturation degree, and presence of naturally occurring or added minor compounds, are of particular relevance (Gere, 1982 and 1983; Boskou, 1988; Dobarganes and MárquezRuiz, 1996). Due to the difficulties encountered to define and/or control such variables and the additional strong interactions existing between them (Jorge et al., 1996a), it is not easy to replicate results from different laboratories and moreover, the conclusions drawn from data obtained under apparently similar conditions might differ greatly.

From the literature, it is generally reported that the main groups of compounds formed during frying are primarily due to the action of temperature and oxygen while diglycerides and free fatty acids, otherwise coming from triglyceride hydrolysis, are the least representative compounds even when frying foods of high moisture content (Sebedio et al., 1990; PérezCamino et al., 1991; Arroyo et al., 1992; Cuesta et al., 1993; Dobarganes et al., 1993; Arroyo et al., 1995; Jorge et al., 1996b).

A number of studies on thermoxidation and frying have been recently carried out in our laboratory to evaluate the performance of low- and high- oleic sunflower oils as substitutes for more saturated fats in continuous and discontinuous frying (Jorge et al., 1996a and 1996b). Particularly, in laboratory frying experiments, results for total polar compounds were 20.4 and $17.2 \%$, for conventional and high-oleic sunflower oils, respectively, after 6 hours under discontinuous frying conditions, and 11.7 and $7.0 \%$ under simulated continuous frying conditions (Jorge et al., 1996b). Nevertheless, highly variable values were obtained in thermoxidation experiments, depending on the conditions established (Jorge et al., 1996a). 
In addition to the extensive information provided by these studies, and based on the results obtained, some complementary experiments have been undertaken in our laboratory with the aim of designing a simple test to evaluate performance of fats and oils under strictly controlled conditions. The procedure proposed simulates the usual conditions of the main variables of the discontinuous frying process, namely, temperature, surface-to-oil volume ratio, presence of air, and hence can be of great utility to compare results between laboratories. Additionally, changes in the variables controlled could be assayed in order to study their action in the process.

\section{EXPERIMENTAL PART}

\subsection{Samples}

Conventional sunflower oil (SO) and high oleic sunflower oil (HOSO) were used. General characteristics of oils were detailed in earlier publications (Sebedio et al., 1996; Jorge et al., 1996a).

\subsection{Heating procedure}

$8 \pm 0.01 \mathrm{~g}$ of oil were weighed out in a Rancimat vessel and inserted in the heating block previously heated at $180 \pm 1^{\circ} \mathrm{C}$. After 10 hours-heating, samples were taken out and kept at $-30^{\circ} \mathrm{C}$ until analyses.

For limited amounts of samples, standard glass tubes of $10 \mathrm{~cm} \times 10 \mathrm{~mm}$ i.d. were used. $2 \pm 0.01 \mathrm{~g}$ of sample were weighed directly into the tube, in turn introduced into the Rancimat reaction vessel containing $6 \mathrm{~g}$ of glycerol to facilitate heat transfer, and inserted in the heating block. Conditions applied were the same described above.

Rancimat instructions were carefully observed for glassware cleaning and temperature correction. No bubbling of air was applied during heating and the reaction vessels were left open.

\subsection{Analytical determinations}

1. Polymerized triglycerides were quantitated directly in the oil samples by high-performance sizeexclusion chromatography (HPSEC) following the IUPAC Standard Method (IUPAC, 1992).

2. Polar compounds and distribution of minor glyceridic compounds were determined by combination of adsorption chromatography and HPSEC (Dobarganes et al., 1988). Briefly, non-polar and polar fractions of oil samples were separated by silica column chromatography, eluting with a mixture 90:10 hexane: diethyl ether and diethyl ether, respectively. Polar fractions were further analyzed by HPSEC in order to quantitate triglyceride oligomers (TGO), triglyceride dimers (TGD), oxidized triglyceride monomers (OxTGM), diglycerides (DG) and free fatty acids (FA).

Conditions applied for HPSEC in both methods were as follows:

A Waters 510 HPLC pump and a Rheodyne $7725 \mathrm{i}$ injector with a $10 \mu \mathrm{m}$ sample loop (Waters Associates, Milford, MA, USA), a refractive index detector (Hewlett Packard, Pittsburg, PA, USA) and two 100 and $500 \AA$ Ultrastyragel columns (Waters Associates, Milford, MA, USA) connected in series, were used. The columns were $25 \mathrm{~cm} \times 0.77 \mathrm{~cm}$ inner diameter, packed with a porous, highly cross-linked styrenedivinylbenzene copolymer $(<10 \mu \mathrm{m})$. High-performance liquid chromatography grade tetrahydrofuran served as the mobile phase with a flow of $1 \mathrm{~mL} / \mathrm{min}$.

Sample solutions of around $50 \mathrm{mg}$ of oil $/ \mathrm{mL}$ and 15 $\mathrm{mg}$ of polar compounds/mL in tetrahydrofuran were used for analyses 1 and 2, respectively.

\section{RESULTS AND DISCUSSION}

Table I shows the results obtained for total polar compounds and polymers in quadruplicate samples of 2 and $8 \mathrm{~g}$ oils heated for $10 \mathrm{~h}$ at $180^{\circ} \mathrm{C}$, under the conditions described in the experimental part.

Table I

Repeatability of the procedure for polymers (wt\%) and total polar compounds (wt\%) determination

in conventional (SO) and high-oleic (HOSO) sunflower oils heated at $180^{\circ} \mathrm{C}$ for $10 \mathrm{~h}$.

\begin{tabular}{|c|c|c|c|c|c|c|c|}
\hline \multirow[b]{2}{*}{ Sample(g) } & \multirow[b]{2}{*}{ ) Oil } & \multicolumn{3}{|c|}{ Polymers } & \multicolumn{3}{|c|}{ Total Polar Compounds } \\
\hline & & Mean ${ }^{*}$ & SD & $\overline{\mathrm{RSD}(\%)}$ & Mean ${ }^{*}$ & SD & RSD(\%) \\
\hline \multirow{2}{*}{2} & HOSO & 8.3 & 0.38 & 4.6 & 17.8 & 0.83 & 4.7 \\
\hline & so & 12.3 & 0.54 & 4.4 & 21.9 & 0.90 & 4.1 \\
\hline \multirow{2}{*}{8} & HOSO & 9.7 & 0.29 & 3.0 & 19.7 & 1.13 & 5.7 \\
\hline & so & 13.8 & 0.43 & 3.3 & 24.3 & 1.12 & 4.6 \\
\hline
\end{tabular}

${ }^{*}$ Results are means of four experiments.

As can be observed, repeatability was very good, the coefficient of variation being lower than $6 \%$ under all circumstances (analytical method, oil unsaturation degree and amount of sample). Differences between the results obtained for 2 and $8 \mathrm{~g}$ samples can be attributed to small differences in the surface-to-oil volume ratio. This variable, showing a slightly higher value in $8 \mathrm{~g}$ samples, has been proved to exert an important influence on the oxidative degradation (Jorge et al., 1996a).

It is important to note that total variations found are due to both heating differences and deviations associated with the analytical method used. 
Considering that repeatability relative standard deviations in the range of the mean values obtained in this study have been reported to be on the order of $3 \%$ (IUPAC, 1987) and $2 \%$ (AOCS, 1994) for polymers and polar compounds determinations, respectively, it can be deduced that heating introduced minimal differences.

Table II presents distribution of the main groups of compounds formed during heating for 10 hours. A similar distribution pattern was obtained as compared to those found for used frying fats with similar level of polar compounds (Jorge et al., 1996b). Thus, higher amounts of polar compounds and, in particular, polymers, were formed in the most unsaturated oil while hydrolytic products, i. e., DG and FA, did not significantly change, since similar levels were already present in the starting oils (data not shown).

Table II

Distribution of polar compounds (wt\%) in triglyceride oligomers (TGO), triglyceride dimers (TGD), oxidized triglyceride monomers (Ox TGM), diglycerides (DG) and fatty acids (FA) in conventional (SO) and high oleic (HOSO) sunflower oils heated at $180^{\circ} \mathrm{C}$ for $10 \mathrm{~h}$.

\begin{tabular}{lllllll}
\hline Sample(g) & Oil & TGO & TGD & Ox TGM & DG & FA \\
\hline \multirow{2}{*}{2} & HOSO & 2.0 & 6.2 & 7.1 & 2.0 & 0.5 \\
& SO & 2.7 & 9.9 & 7.6 & 1.2 & 0.5 \\
& & & & & & \\
\multirow{2}{*}{8} & HOSO & 2.6 & 6.8 & 7.9 & 1.9 & 0.5 \\
& SO & 3.3 & 10.2 & 9.1 & 1.3 & 0.4 \\
\hline
\end{tabular}

On the other hand, it is important to note that values for total polymers as determined directly in the entire oil samples (Table I) fitted very well with results obtained for dimers plus oligomers, as quantitated in total polar compound fractions (Table II) despite the substantial difference between both determinations, that is, the presence of the most abundant group of compounds constituted by non-polar triglycerides in the total sample, otherwise eliminated in fractions of isolated polar compounds. Therefore, such consistent results indirectly indicated that response factors for the different groups of compounds, including non-polar triglycerides, are of the same order and hence not only repeatability but also accuracy of both determinations were highly satisfactory.

It is essential to point out that the values used for the variables were carefully selected:

a) Temperature established was that most representative of frying procedures.

b) Length of heating was decided as to achieve levels of polar compounds close to those normally found in used frying fats. Limitations established in some European countries, around $16 \%$ of polymers and $25 \%$ of polar compounds (Firestone, 1996) were considered to set up the maximum alteration levels obtained.

c) Sample amount was selected as to fulfill two requirements:

- A surface-to-oil volume ratio as low as possible in order to resemble that used in domestic discontinuous frying. Hence a value around $0.4 \mathrm{~cm}^{-1}$ was established in the procedure proposed while it oscilates between 0.3 and $0.5 \mathrm{~cm}^{-1}$ in small domestic fryers (Jorge et al., 1996b)

- Complete introduction of the sample in the heating block in order to guarantee homogeneous heating.

Table III reflects the outstanding influence of apparently small changes in sample amounts on the oil degradation level. Results included correspond to duplicate experiments. It is observed that, as the surface-to-oil volume ratio decreased from 5 to $9 \mathrm{~g}$ samples, alteration dropped as expected but then, for $10 \mathrm{~g}$-samples, levels of polymers increased significantly, considering the good repeatability data already commented. From this point forward, a further decrease in the surface-to-oil volume ratio exerted again the expected effect in lowering alteration. A likely explanation for these results could be the different and concomitant action of two variables: surface-to-oil volume ratio and occurrence of convection currents (Jorge et al., 1996a). In fact, when oil amount approaches around $10 \mathrm{~g}$, the effective heating zone of the aluminum block is overpassed and thus the convection currents due to the higher temperature gradient created would contribute to increase oxidation in a greater extent than the opposite effect resulting from a parallel decrease in surface-to-oil volume ratio. Interestingly, these findings do not bring about any drawback for the procedure but add further possibilities of applications since testing amounts over $10 \mathrm{~g}$ could be of great utility to check the action of compounds with potential surface protective properties.

Table III

Influence of sample amount (g) on polymers (wt\%) formed after heating conventional sunflower oil (SO) for 5 and $10 \mathrm{~h}$ at $180^{\circ} \mathrm{C}$.

\begin{tabular}{|c|c|c|c|c|}
\hline \multirow{3}{*}{$\frac{\text { Sample amount }(\mathrm{g})}{5}$} & \multicolumn{4}{|c|}{ Period of heating (h) } \\
\hline & \multicolumn{2}{|c|}{5} & \multicolumn{2}{|c|}{10} \\
\hline & $7.6^{*}$ & $7.8^{*}$ & 15.8 & 16.3 \\
\hline 8 & 5.9 & 6.2 & 12.2 & 12.6 \\
\hline 9 & 5.1 & 5.3 & 10.0 & 10.7 \\
\hline 10 & 6.7 & 7.1 & 12.9 & 13.5 \\
\hline 12 & 5.0 & 4.7 & 10.1 & 9.8 \\
\hline 15 & 4.5 & 4.6 & 8.9 & 9.5 \\
\hline
\end{tabular}

${ }^{\star}$ Duplicate experiments

Also, evolution of polymer formation was followed throughout the heating period in quadruplicate experiments and results are included in Table IV. 
Samples of $50 \mathrm{mg}$ were withdrawn after 2, 4, 6, 8 and 10 $\mathrm{h}$ and polymerized compounds were quantitated directly in the oil samples $(8 \mathrm{~g})$ according to the IUPAC method. Repeatability was checked and data are also listed in Table IV. Results showed that, under the conditions used, the increase in polymers was linear from 0 to 10 hours. A highly significant correlation was obtained, the coefficients being 0.999 and 0.984 for HOSO and SO, respectively, and the slopes differed from 0.95 to 1.19 , respectively, thus denotating the higher tendency to polymerization of the unsaturated oil.

Table IV

Evolution of polymer (wt\%) formation in conventional (SO) and high-oleic (HOSO) sunflower oils heated at $180^{\circ} \mathrm{C}$.

\begin{tabular}{ccccccccc}
\hline & \multicolumn{3}{c}{ HOSO } & & \multicolumn{3}{c}{ SO } \\
\cline { 2 - 3 } \cline { 7 - 8 } Period of heating (h) & Mean* & SD & RSD(\%) & & Mean* & SD & RSD(\%) \\
\hline 0 & 0.2 & 0.02 & 10.0 & & 0.6 & 0.01 & 1.7 \\
2 & 2.1 & 0.19 & 9.0 & & 3.6 & 0.32 & 8.9 \\
4 & 3.9 & 0.30 & 7.7 & & 6.1 & 0.64 & 10.5 \\
6 & 6.0 & 0.29 & 4.8 & & 8.9 & 0.49 & 5.5 \\
8 & 7.8 & 0.42 & 5.4 & & 11.2 & 0.59 & 5.3 \\
10 & 9.7 & 0.29 & 3.0 & & 13.8 & 0.43 & 3.2 \\
\hline
\end{tabular}

'Results are means of four experiments.

Overall, it is worth remarking that the main advantage of this heating procedure by using Rancimat apparatus is the elimination of the most important drawbacks found to set up a standard method to compare results from different laboratories. Given the characteristics of the apparatus, i. e., standard vessels, temperature correction, homogenity of temperature in tubes, excellent control of temperature, some important variables can be standardized, such as temperature, surface-to-oil volume ratio, heating time, type of heating, thus allowing the study of the influence of the different variables of the frying process.

Among the possible applications, this procedure can be useful to check the action of minor compounds. As an example, Table $\mathrm{V}$ shows the results obtained after heating $2 \mathrm{~g}$ of $\mathrm{HOSO}$ and $\mathrm{SO}$ with naturally occurring and devoid of tocopherols, essentially $a$ tocopherol, and other minor compounds, eliminated by aluminum oxide following the method of Yoshida et al., 1992. Highly significant differences were found between starting oils and their counterparts lacking tocopherols thus suggesting that the antioxidant action of a-tocopherol at high temperature cannot be underestimated. The procedure has been extensively used to know the action of natural antioxidants in oils of different unsaturation degree and tocopherol content, and results and conclusions will be shortly communicated.
Table V

Influence of tocopherols in polymers (wt\%) and polar compounds (wt\%) formation in conventional (SO) and high-oleic (HOSO) sunflower oils heated at $180^{\circ} \mathrm{C}$ for $10 \mathrm{~h}$.

\begin{tabular}{|c|c|c|c|c|c|}
\hline \multirow[t]{2}{*}{ Sample } & \multirow{2}{*}{$\begin{array}{c}a \text {-Tocopherol } \\
(\mathrm{mg} / \mathrm{Kg})\end{array}$} & \multicolumn{2}{|c|}{ Polymers } & \multicolumn{2}{|c|}{ Polar compounds } \\
\hline & & Mean & SD & Mean & SD \\
\hline \multirow{2}{*}{ HOSO } & $650^{*}$ & 8.3 & 0.38 & 17.8 & 0.50 \\
\hline & $n \cdot d^{\star \star}$ & 11.2 & 0.50 & 21.4 & 0.85 \\
\hline \multirow{2}{*}{ SO } & $603^{*}$ & 12.3 & 0.54 & 21.9 & 0.28 \\
\hline & n.d. ${ }^{* *}$ & 16.8 & 0.28 & 26.2 & 1.13 \\
\hline
\end{tabular}

${ }^{*}$ Results are means of four experiments

** Results are means of two experiments

\section{ACKNOWLEDGEMENT}

This study was funded by CICYT (Project ALI-950736). The authors thank Mercedes Giménez for assistance. Daniel Barrera Arellano was supported by a postdoctoral fellowship (95/9304-2) from Fundação de Apoío à Pesquisa do Estado de São Paulo (FAPESP).

\section{BIBLIOGRAPHY}

AOCS (1994). -Method Cd 20-91 in «Official methods and recommended practices of the American Oil Chemists' Society" 4th ed.- AOCS, Champaign.

Arroyo, R., Cuesta, C., Garrido-Polonio, C., López-Varela, S. and Sánchez-Muniz, F. J. (1992). -«High-performance size-exclusion chromatographic studies on polar components formed in sunflower oil used for frying".- J. Am. Oil Chem. Soc. 69, 557-563.

Arroyo, R., Cuesta, C., Sánchez-Muniz, F. J. (1995). -«High performance size- exclusion chromatography of palm olein used for frying»- Fat Sci. Technol. 97, 292-296.

Boskou, D. (1988). - «Stability of frying oils" in "Frying of Food. Principles, Changes, New Approaches», pp. 174182.- G. Varela, A. E. Bender and I. D. Morton (Ed. Ellis Horwood Ltd., Chichester (England).

Cuesta, C., Sánchez-Muniz, F. J., Garrido-Polonio, C., LópezVarela, S. and Arroyo, R. (1993).- "Thermoxidative and hydrolytic changes in sunflower oil used in fryings with a fast turnover of fresh oil»- J. Am. Oil Chem. Soc. 70, 1069-1073.

Dobarganes, M. C., Pérez-Camino, M. C. and Márquez-Ruiz, G. (1988). - «High performance size exclusion chromatography of polar compounds in heated and nonheated fats". - Fat Sci. Technol. 90, 308-311.

Dobarganes, M. C., Márquez Ruiz, G. and Pérez-Camino, M. C. (1993). - «Thermal stability and frying performance of genetically modified sunflower seed (Helianthus annuus L.) oils".- J. Agric. Food Chem. 41, 678-681. 
Dobarganes, M. C. and Márquez Ruiz, G. (1996). -«Dimeric and higher oligomeric triglycerides" in "Deep Frying. Chemistry, Nutrition and Practical Applications», pp. 89111.- E. G. Perkins and M. D. Erickson (Ed.).- -American Oil Chemists' Society, Champaign, Illinois.

Firestone, D. (1996). - «Regulation of frying fat and oil» in «Deep Frying. Chemistry, Nutrition and Practical Applications", pp. 89-111.- E. G. Perkins and M. D. Erickson (Ed.).- American Oil Chemists' Society, Champaign, Illinois.

Gere, A. (1982).- «Decrease in essential fatty acid content of edible fat during the frying process". $-Z$. Ernährungswiss. 21, 191-201.

Gere, A. (1983). -Study of some factors affecting frying fat deterioration».- Fette Seifen Anstrichm. 85, 18-23.

IUPAC. (1992). -Method 2.508 in «Standard methods for the analysis of oils, fats and derivatives".- 7th edition, Pergamon Press, Oxford.

Jorge, N., Márquez-Ruiz, G., Martín-Polvillo, M., RuizMéndez, M. V. and Dobarganes, M. C. (1996a). - Influence of dimethylpolysiloxane addition to edible oils: dependence on the main variables of the frying process".- Grasas y Aceites, 47, 14-19.

Jorge, N., Márquez-Ruiz, G., Martín-Polvillo, M., RuizMéndez, M. V. and Dobarganes, M. C. (1996b).
-«Influence of dimethylpolysiloxane addition to frying oils: performance of sunflower oil in discontinuous and continuous laboratory frying".- Grasas y Aceites, 47, 20-25

Pérez-Camino, M. C., Márquez Ruiz, G., Ruiz-Méndez, M. V. and Dobarganes, M. C. (1991). - "Lipid changes during frying of frozen prefried foods».- J. Food Sci. 56, 16441650.

Sebedio, J. L., Bonpunt, A., Grandgirard, A. and Prevost, J. (1990). - «Deep fat frying of frozen prefried french fries: Influence of the amount of linoleic acid in the frying medium».- J. Agric. Food Chem. 38, 1862-1867.

Sebedio, J. L., Dobarganes, M. C., Márquez, G., Wester, I., Christie, W. W., Dobson, G., Zwoboda, F., Chardigny, J. M., Mairot, Th. and Lahtinen, R. (1996). -«Industrial production of crisps and prefried french fries using sunflower oils".- Grasas y Aceites, 47, 5-13.

Yoshida, H., Kondo, I. and Kajimoto, G. (1992). - «Participation of free fatty acids in the oxidation of purified soybean oil during microwave heating".- J. Am. Oil Chem. Soc. 69, 1136-1140.

Recibido: Agosto 1997 Aceptado: Agosto1997 